\title{
ANALISIS RUANG TERBUKA HIJAU (RTH) KOTA MANADO
}

\author{
Ravena R. R. Pangemanan \\ O. Esry. H. Laoh \\ Theodora M. Katiandagho
}

\begin{abstract}
This study aims to identify the Green Open Space of Manado City and to study the Green Open Space in Manado City by comparing with the determination of green open space based on Law No. 26 of 2007 article 29 on spatial planning. The study was conducted from February to Jully 2017, using secondary data. Secondary data were obtained from the Central Bureau of Statistics (BPS) of Manado City, and the Office of the Regional Development Planning Board (BAPPEDA) of Manado City. Data analysis used is availability analysis, requirement analysis (by area), and adequacy analysis. The results showed that the availability of public green space in Manado City has not reached the target or 20\% for public open space and in Manado City there are only 2283,25 hectares or around 14,51\%, while for private Green Open Space in Manado city is very wide as 9825,14 hectares or around 62,47\%, has exceeded up to six times the private Green Open Space target of $10 \%$. For that presumably the government can regulate the spatial related to Green Open Space in an effort to improve environmental quality in Manado City, especially in public green space that is still less than the target.
\end{abstract}

Keyword: green open space, spatial planning, Manado City

\begin{abstract}
ABSTRAK
Penelitian ini bertujuan untuk mengidentifikasi RTH Kota Manado serta untuk mengkaji RTH di Kota Manado dengan membandingkan dengan penetapan RTH berdasarkan Undang-Undang No 26 Tahun 2007 pasal 29 tentang penataan ruang. Penelitian dilaksanakan pada bulan February sampai Jully 2017, menggunakan data sekunder. Data sekunder diperoleh dari Badan Pusat Statistik (BPS) Kota Manado, dan Kantor Badan Perencanaan Pembangunan Daerah (BAPPEDA) Kota Manado. Analisis data yang digunakan adalah analisis ketersediaan, analisis kebutuhan (berdasarkan luas wilayah), dan analisis kecukupan. Hasil penelitian menunjukkan bahwa ketersediaan RTH publik di Kota Manado belum sesuai standar atau belum mencapai target yaitu 20\% untuk RTH publik di Kota Manado hanya terdapat 2283,25 hektar atau berkisar 14,51\%, sedangkan untuk RTH privat di Kota Manado sangat luas sebesar 9825,14 hektar atau berkisar 62,47\%, telah melebihi hingga enam kali lipat dari target RTH privat yaitu 10\%. Untuk itu kiranya pemerintah dapat mengatur tata ruang yang terkait dengan RTH dalam upaya peningkatan kualitas lingkungan di Kota Manado terutama pada RTH publik yang masih kurang dari target.
\end{abstract}

Kata Kunci: ruang terbuka hijau, penataan ruang, Kota Manado 


\section{PENDAHULUAN}

\section{Latar Belakang}

Ruang Terbuka Hijau (RTH) di wilayah perkotaan merupakan bagian dari penataan ruang kawasan perkotaan yang memiliki manfaat kehidupan yang sangat tinggi, tidak saja dapat menjaga dan mempertahankan kualitas lingkungan tapi juga dapat menjadi nilai kebanggaan identitas kota. RTH adalah bagian dari ruang terbuka yang diisi oleh tanaman, tumbuhan dan vegetasi guna mendukung manfaat langsung dan atau tidak langsung yang dihasilkan RTH yaitu kenyamanan, kesejahteraan dan keindahan wilayah yang terdapat dalam RTH tersebut. RTH yang ideal adalah 30\% dari luas wilayah (Hakim, 2010). Berdasarkan status kepemilikan RTH diklasifikasikan menjadi (a) RTH publik yaitu RTH yang berlokasi dilahan-lahan milik pemerintah, dan (b) RTH privat atau non publik yaitu RTH yang berlokasi pada lahanlahan milik pribadi. Kota Manado adalah salah satu kawasan perkotaan di Indonesia cenderung mengalami permasalahan dalam perkotaan yaitu tingginya tingkat pertumbuhan penduduk sehingga menyebabkan pengelolaan ruang kota makin berat. Jumlah penduduk perkotaan yang tinggi dan terus meningkat tersebut menyebabkan tingginya tekanan terhadap pemanfaatan ruang kota, sehingga penataan ruang kawasan perkotaan perlu mendapat perhatian yang khusus, terutama yang terkait dengan penyediaan kawasan hunian, fasilitas umum dan sosial serta ruang-ruang terbuka di perkotaan. Hal ini mengakibatkan banyaknya lahan-lahan bervegetasi yang telah dialih fungsikan menjadi pemukiman, kompleks perbelanjaan, perkantoran dan lainnya sehingga menyebabkan berkurangnya RTH dan menurunkan kualitas lingkungan karena dianggap sebagai lahan cadangan dan tidak ekonomis. Berkurangnya kuantitas maupun menurunnya kualitas RTH dapat menimbulkan berbagai masalah lingkungan seperti banjir, tingginya polusi udara serta menurunnya produktivitas masyarakat karena terbatasnya ruang untuk interaksi sosial. Salah satu faktor untuk menyeimbangkan keadaan lingkungan Kota Manado yang sudah padat yaitu dengan adanya RTH. Kawasan RTH dapat merupakan tempat interaksi sosial bagi masyarakat yang dapat memberikan kenyamanan untuk masyarakat serta menjadi tempat berekreasi dan hiburan keluarga bagi masyarakat tersebut. Keberadaan RTH sangatlah banyak jenisnya, yaitu RTH alami dan buatan seperti taman kota, jalur hijau, kebun dan pekarangan, serta hutan kota. RTH perlu di rencanakan agar dapat mengatur dan mengelola ruang atau lahan sehingga memberikan keseimbangan lingkungan kota secara optimal. Pentingnya diperhatikan permasalahan penyediaan RTH di Kota Manado sehingga peneliti memiliki ketertarikan untuk melakukan penelitian mengenai Analisis Kebutuhan Ruang Terbuka Hijau di Kota Manado. Kota Manado sendiri memiliki banyak penduduk karena terletak di kawasan pusat kota, dengan fungsi perkantoran, jasa, perdagangan dan kawasan pemukiman yang padat penduduk.

\section{Perumusan Masalah}

Berdasarkan latar belakang tersebut, maka perumusan masalah adalah sebagai berikut:

1. Bagaimana keadaan RTH yang ada di Kota Manado ?

2. Apakah RTH di Kota Manado sudah sesuai dengan Undang-Undang No 26 Tahun 2007 Pasal 29 tentang penataan ruang bahwa perlu adanya penyediaan RTH sebesar $30 \%$ dari luas wilayah?

\section{Tujuan Penelitian}

Berdasarkan perumusan masalah, maka yang menjadi tujuan penelitian ini adalah:

1. Untuk mengidentifikasi RTH Kota Manado.

2. Untuk mengkaji RTH di Kota Manado dibandingkan dengan penetapan RTH berdasarkan Undang-Undang No 26 Tahun 2007 Pasal 29 tentang Penataan Ruang.

\section{Manfaat Penelitian}

Manfaat dari penelitian ini adalah

1. Sebagai tambahan ilmu bagi peneliti mengenai RTH, terutama yang ada di kota Manado. Dan penelitian ini merupakan salah satu syarat untuk memperoleh gelar sarjana di fakultas pertanian Universitas Sam Ratulangi Manado.

2. Sebagai suatu bahan referensi bagi penelitianpenelitian lainnya. 


\section{METODOLOGI PENELITIAN}

\section{Waktu dan Tempat Penelitian}

Penelitian ini dilaksanakan di Kota Manado Provinsi Sulawesi Utara, terletak pada koordinat $124^{\circ} 40^{\prime} 40.80^{\prime \prime}$ hingga $124^{\circ} 55^{\prime}$ 54.48" BujurTimur dan $1^{\circ} 26^{\prime} 15.00^{\prime \prime}$ hingga $1^{\circ}$ 38' 58.56" Lintang Utara dengan luasan sekitar 15.726 ha. Dan pelaksanaan penelitian berlangsung di mulai dari bulan February sampai bulan Jully 2017.

\section{Metode Pengumpulan Data}

Metode pengumpulan data yang digunakan pada penelitian ini adalah data sekunder yaitu data yang diperoleh dari Badan Pusat Statistik (BPS) Kota Manado, Kantor Badan Perencanaan Pembangunan Daerah (BAPPEDA) Kota Manado, dan Dinas Lingkungan Hidup Kota Manado.

\section{Metode Analisis Data}

Metode analisis dilakukan untuk menghitung kebutuhan luas RTH berdasarkan Luas Wilayah menurut UU No.26 Tahun 2007, Kebutuhan Luas RTH yang harus dipenuhi sebuah kota berkaitan dengan tata ruang wilayah yang diatur dalam Undang-undang No 26 tahun 2007 tentang penataan ruang, yakni minimal $30 \%$ dari luas wilayah kota. Bentuk RTH dapat berupa RTH alami maupun RTH buatan yang dimiliki secara pribadi maupun umum. Pada penelitian ini analisis yang digunakan yaitu Analisis Ketersedian RTH, Analisis Kebutuhan RTH, dan Analisis Kecukupan RTH.

\section{Analisis Ketersediaan RTH}

Analisis ketersediaan RTH dilakukan untuk mengetahui jumlah eksisting ketersediaan RTH, jenis RTH, luas RTH, serta sebaran RTH yang ada di lokasi penelitian. Analisis yang digunakan yaitu mengidentifikasi ketersediaan RTH dari data sekunder yang diperoleh.

\section{Analisis Kecukupan RTH}

Analisis kecukupan RTH Publik dilakukan dengan membandingkan ketersediaan RTH dengan kebutuhan RTH berdasarkan luas wilayah.

\section{Konsep Pengukuran Variabel}

Variabel-variabel yang diukur dalam penelitian ini adalah :

1. Luas wilayah kota Manado

2. Luas wilayah per kecamatan di Kota Manado.

3. Luas RTH di setiap kecamatan di Kota Manado, dan

4. Jumlah penduduk per kecamatan di Kota Manado.

\section{HASIL DAN PEMBAHASAN}

\section{Deskripsi Wilayah Penelitian}

\section{Luas Wilayah}

Secara geografis, Kota Manado terletak di antara : $1^{\circ} 30^{\prime}-1^{\circ} 40^{\prime}$ Lintang Utara dan $124^{\circ} 40^{\prime}-126^{\circ} 50^{\prime}$ Bujur Timur. Peta administrasi Kota Manado ditunjukan pada gambar 1.

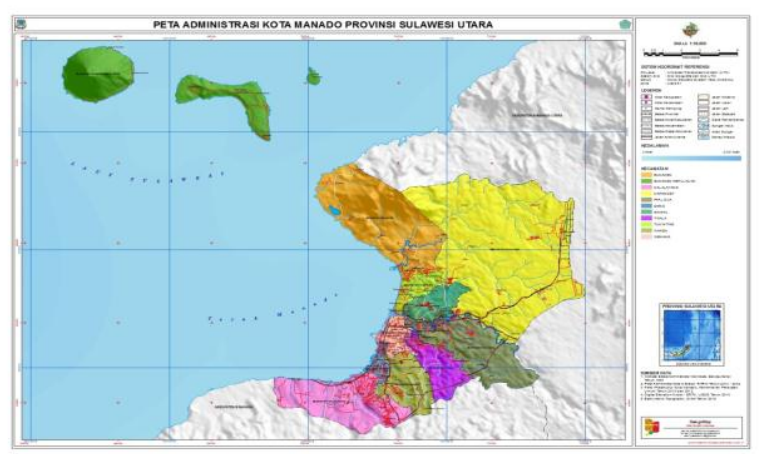

Gambar 1. Peta Administrasi Kota Manado Sumber : BAPPEDA Kota Manado

Kota Manado terdiri dari 11 Kecamatan antara lain kecamatan Malalayang, Sario, Wanea, Wenang, Tikala, Paal dua, Mapanget, Singkil, Tuminting, Bunaken, dan Kepulauan Bunaken dengan luas wilayah keseluruhan $15.726 \mathrm{Ha}$. Luas wilayah berdasarkan kecamatan dapat dilihat pada Tabel 1. Pada Tabel 1, Luas wilayah terbesar di Kota Manado terdapat pada Kecamatan Mapanget, kemudian Kecamatan Bunaken, Kecamatan Malalayang, Kecamatan Kepulauan Bunaken, Kecamatan Paal 2, Kecamatan Wanea, Kecamatan Tikala, Kecamatan Singkil, Kecamatan Tuminting, Kecamatan Wenang dan luas wilayah terkecil pada Kecamatan Sario. Batas-batas wilayah Kota Manado adalah sebagai berikut : Sebelah Utara dengan Kec. Wori (Kab. Minahasa Utara) \& Teluk Manado, Sebelah Timur 
dengan Kec. Dimembe (Kab. Minahasa Utara) dan Kec. Pineleng (Kab. Minahasa), Sebelah Selatan dengan Kec. Pineleng (Kab. Minahasa) dan Sebelah Barat dengan Teluk Manado / Laut Sulawesi.

\section{Jumlah Penduduk}

Jumlah penduduk kota Manado berjumlah 524.206 jiwa dengan penggolongan jumlah laki-laki 263.066 jiwa dan perempuan 261.140 jiwa. Untuk jumlah penduduk terbanyak terdapat pada Kecamatan Malalayang dengan jumlah 63.370 jiwa dan jumlah penduduk terkecil atau sedikit pada Kecamatan Kepulauan Bunaken dengan jumlah 7.783 jiwa. Jumlah penduduk keseluruhan berdasarkan kecamatan dapat dilihat pada Tabel 2 .

\section{Identifikasi Ruang Terbuka Hijau}

Berdasarkan status kepemilikan RTH diklasifikasikan menjadi (a) RTH publik, yaitu RTH yang berlokasi pada lahan-lahan publik atau lahan yang dimiliki oleh pemerintah (pusat, daerah), dan (b) RTH privat atau non publik, yaitu RTH yang berlokasi pada lahan-lahan milik privat atau pribadi. Identifikasi RTH kota Manado dapat dilihat pada lampiran 1.

\section{RTH Taman Kota}

Taman kota merupakan ruang didalam kota yang ditata untuk menciptakan keindahan, kenyamanan, dan kesehatan bagi penggunanya. Selain itu, taman kota difungsikan sebagai paru-paru kota, pengendali iklim mikro, serta konservasi tanah dan air. Pepohonan yang ada dalam taman kota dapat memberikan manfaat keindahan, penangkal angin, dan penyaring cahaya matahari. Taman kota berperan sebagai sarana pengembangan budaya kota, pendidikan, dan pusat kegiatan kemasyarakatan. Taman kota harus nyaman secara spasial atau keruangan, dimana warga kota dapat menggunakannya untuk aktivitas informal sehari-hari seperti istirahat, duduk, bermain dan lainnya. Kota Manado mempunyai beberapa taman kota diantaranya : Taman Sparta Tikala (Depan Kantor Walikota Manado) di Kecamatan Tikala dengan luasan 1.323,46 m2, Taman Kesatuan Bangsa (Pusat Kota) di
Kecamatan Wenang dengan luasan $825 \mathrm{~m} 2$, Taman Megasurya Nusa Lestari (Megamas) dengan luasan $1.350 \mathrm{~m} 2$, serta Taman God Bless (God Bless Park) yang saat ini di fungsikan oleh masyarakat Kota Manado sebagai tempat rekreasi, bermain, dan kuliner. RTH taman kota pada Kota Manado salah satunya dapat dilihat pada Gambar 2 yang merupakan hasil gambar diambil di depan Kantor Walikota. Manado Kecamatan Tikala yaitu Taman Sparta Tikala. Sedangkan Pada gambar 3 merupakan RTH Taman Kota yang berlokasi pada area Kawasan Megamas Kecamatan Wenang yang disebut Taman Megamas. Taman ini memiliki banyak peran selain sebagai tempat berekreasi, berolahraga, juga merupakan tempat beberapa kegiatan seperti konser, pameran dan kegiatan lainnya.

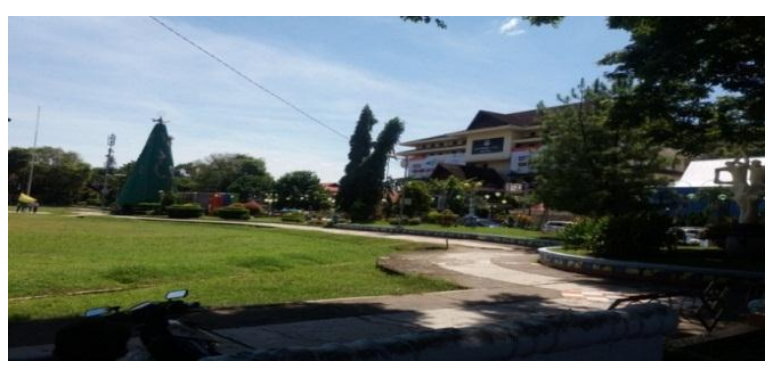

Gambar 2. Taman Sparta Tikala (Depan Kantor Walikota Manado) Kecamatan Tikala

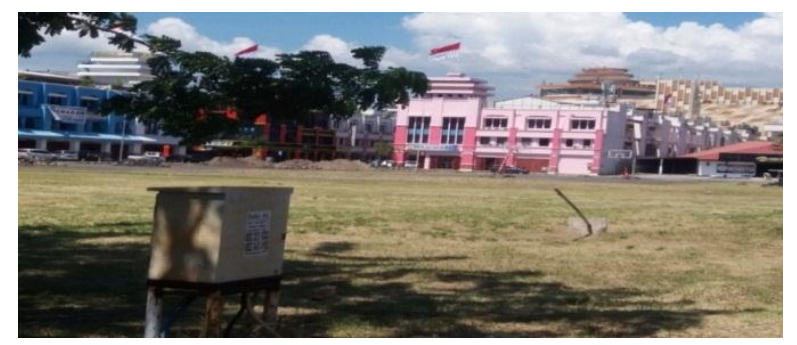

Gambar 3. Taman Megamas Kecamatan Wenang

\section{RTH Hutan Kota}

Hutan Kota merupakan suatu hamparan lahan yang bertumbuhan pohonpohon, yang ditetapkan sebagai hutan kota oleh pejabat yang berwenang. Hutan kota mempunyai beberapa fungsi seperti memperbaiki dan menjaga iklim mikro dan nilai estetika, meresapkan air, menciptakan keseimbangan dan keserasian lingkungan fisik kota, dan mendukung pelestarian keanekaragaman hayati. Hutan kota dapat dimanfaatkan sebagai tempat pariwisata alam, rekreasi, olah raga, penelitian dan 
pengembangan, pendidikan, dan pelestarian plasma nutfah. Hutan Kota di Kota Manado terdapat dibeberapa tempat yaitu Gunung Tumpa (Gambar $4 \mathrm{a}$ dan b) yang terletak pada Kelurahan Tongkeina, Meras dan Molas Kecamatan Bunaken, RSUP Prof. Dr Kandou (Gambar 4c) Kecamatan Malalayang, dan Kampus Universitas Sam Ratulangi Manado (Gambar 4d) Kecamatan Malalayang. Sebenarnya ada beberapa tempat yang dijadikan lokasi Hutan Kota, tetapi saat ini lokasi-lokasi tersebut sudah dibangun permukiman penduduk seperti, Reklamasi (Mall Bahu) dan Hutan di Paniki Bawah. Pada Gambar 5 a dan 5 b merupakan gambar RTH Hutan kota yang ada di Kota Manado yaitu RTH RS. Prof Kandouw Kecamatan Malalayang. Lokasi RS. Prof Kandouw Malalayang, RTHnya sangat terawat, indah dan bersih. Untuk lebih jelas dapat dilihat pada Gambar 5.

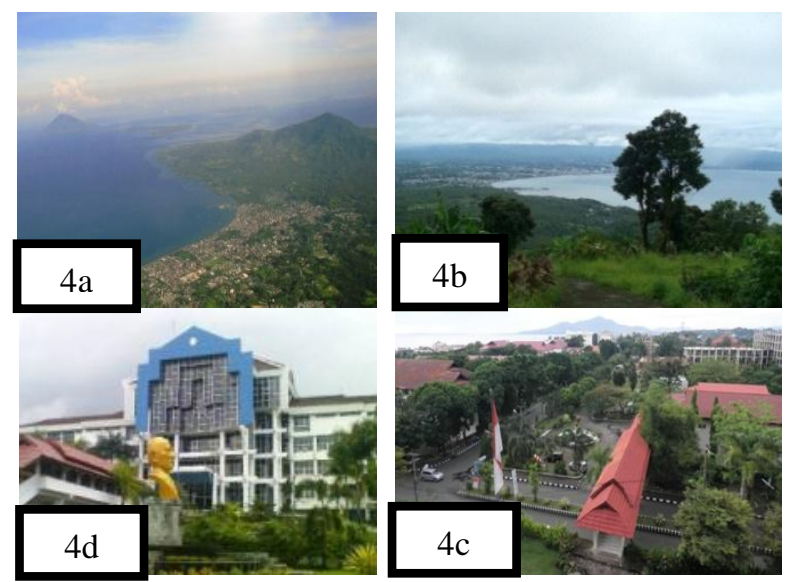

Gambar 4a dan 4b RTH Hutan Kota Gunung Tumpa, 4c RTH RS. Prof. Kandou dan 4d RTH Kampus Universitas Sam Ratulangi
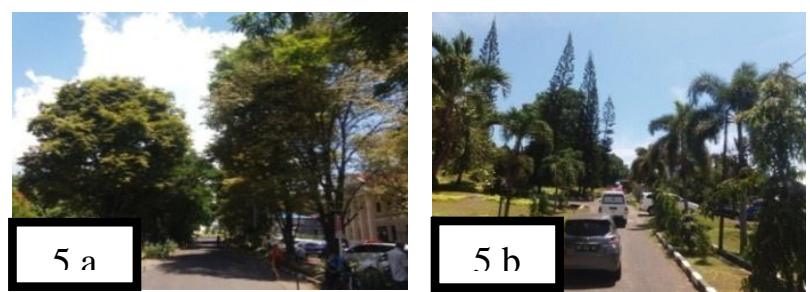

Gambar 5. RTH Hutan Kota RS. Prof Kandou Kecamatan Malalavang Kota Manado.

\section{RTH Jalur Hijau Jalan}

Jalur hijau jalan adalah pepohonan, rerumputan, dan tanaman perdu yang ditanam pada pinggiran jalur pergerakan di samping kirikanan jalan dan median jalan. RTH jalur pengaman jalan terdiri dari RTH jalur pejalan kaki, taman pulau jalan yang terletak di tengah persimpangan jalan, dan taman sudut jalan yang berada di sisi persimpangan jalan. Beberapa fungsi jalur hijau jalan yaitu sebagai penyegar udara, peredam kebisingan, mengurangi pencemaran polusi kendaraan, perlindungan bagi pejalan kaki dari hujan dan sengatan matahari, pembentuk citra kota, dan mengurangi peningkatan suhu udara. RTH Jalur Hijau Jalan di Kota Manado berada pada jalanjalan utama di Pusat Kota seperti Jalan Sudirman, Jalan Samratulangi, Jalan Toar, Jalan Piere Tendean, Jalan Yos Sudarso dan Jalan Monginsidi, dan beberapa ruas jalan lainnya. Sebagian jalur hijau tersebut sudah tertata sesuai dengan fungsinya dengan tanaman berupa jenis kayu, perdu/semak, dan penutup tanah, akan tetapi ada juga jalur hijau jalan yang dipasang paving block dan ditanam pohon ditengahnya. Pada gambar 6a merupakan kondisi jalur hijau di Jln Sutomo Kecamatan Wenang, 6 b kondisi jalur hijau pada kelurahan Bahu Kecamatan Malalayang, dan gambar $6 c$ dan 6d merupakan kondisi jalur hijau di Jln Piere Tendean. Sedangkan pada gambar 7 dapat dilihat RTH Jalur hijau jalan yang merupakan taman kecil, pulau jalan dan taman sudut jalan. Gambar yang diambil pada Gambar 7 merupakan Jalur hijau jalan yang berlokasi pada area Kawasan Megamas Kecamatan Wenang dan taman kecil pada Kecamatan Paal Dua.

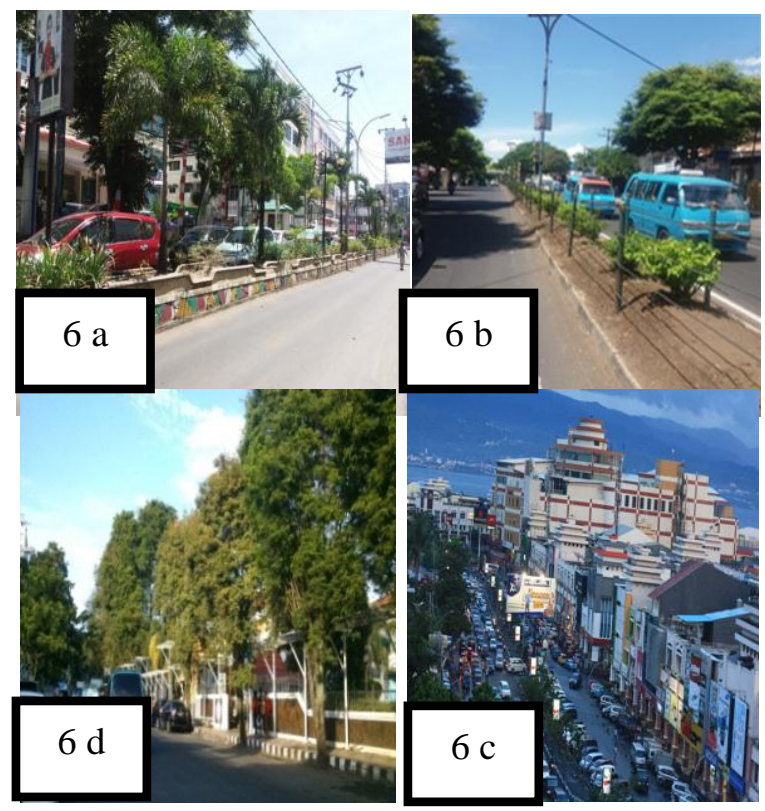

Gambar 6. Kondisi RTH Jalur Hijau Di Beberapa Ruas Kota Manado. 


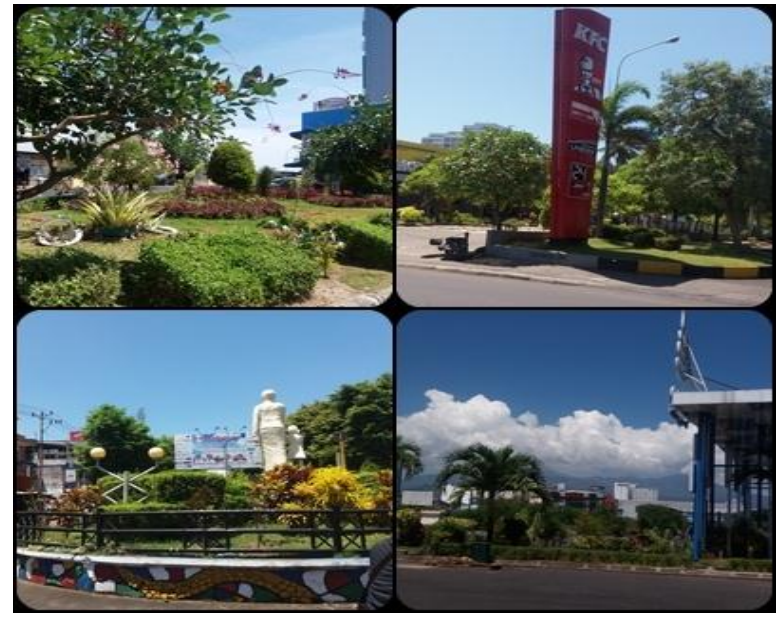

Gambar 7. RTH Jalur Hijau Jalan Taman kecil, Pulau Jalan, dan Taman Sudut Jalan

\section{RTH Jalur Sempadan Sungai}

Sempadan sungai adalah kawasan sepanjang kiri kanan sungai termasuk sungai buatan dan saluran irigasi primer yang mempunyai manfaat penting untuk mempertahankan kelestarian fungsi sungai, mengamankan aliran sungai, dan dikembangkan sebagai area penghijauan. Fungsi lain dari sempadan adalah untuk penyerap aliran air, perlindungan habitat, dan perlindungan dari bencana alam. Kota Manado memiliki sungai Tondano yang juga adalah sungai terbesar di Provinsi Sulawesi Utara yang mengalir dari Tondano (Kabupaten Minahasa) sampai Kota Manado, di Kota Manado hanya terdapat anak-anak sungai tempat bermuara seperti sungai Bahu, Sungai Sario, Sungai Tikala, dan sebagainya. Pada Gambar 8 merupakan gambar RTH sempadan sungai yang berlokasi di Kelurahan Bahu Kecamatan Malalayang.

\section{RTH Jalur Sempadan Pantai}

Sempadan Pantai adalah RTH yang berfungsi sebagai batas dari pantai, kawasan limitasi terhadap penggunaan lahan disekitarnya. Fungsi lain dari sempadan adalah untuk penyerap aliran air, perlindungan habitat, dan perlindungan dari bencana alam. Kota Manado yang hanya terdapat sempadan pantai yaitu pada kecamatan Malalayang, Bunaken, dan Kepulauan Bunaken. RTH Jalur sempadan pantai kecamatan Bunaken dapat dilihat pada gambar $9 a$ dan $9 b$.

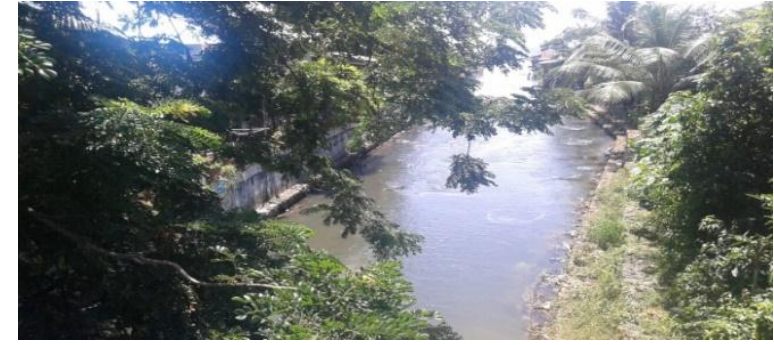

Gambar 8. RTH Sempadan Sungai Bahu Kecamatan Malalayang

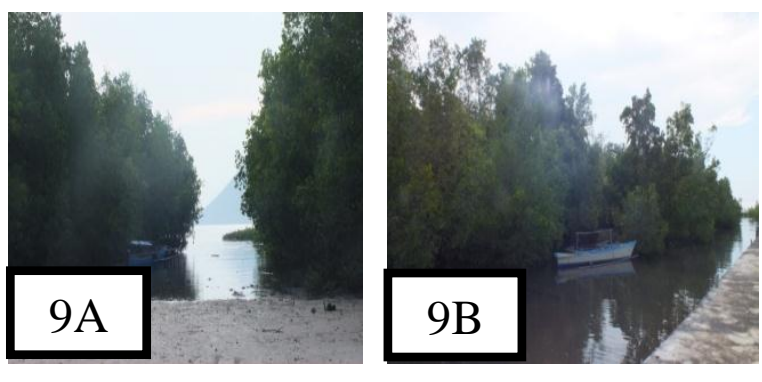

Gambar 9. RTH Sempadan Sungai Bahu Kecamatan Malalayang

\section{RTH Lapangan Olahraga}

Lapangan olahraga merupakan lapangan yang dibangun untuk menampung berbagai aktifitas olahraga seperti sepak bola, voli, atletik, dan golf serta sarana-sarana penunjangnya. Fungsi lapangan olahraga pertemuan, adalah sebagai sarana wadah interaksi dan olahraga, tempat sosialisasi, bermain, serta untuk meningkatkan kualitas lingkungan sekitarnya. RTH lapangan olahraga yang terdapat di Kota Manado antara lain, lapangan Sparta Tikala (Gambar 10a) yang selain sebagai RTH taman kota juga merupakan RTH lapangan olahraga, lapangan kampus Unsrat, lapangan Bantik Kecamatan Malalayang (Gambar 10b), lapangan Sario KONI, lapangan Stadion Klabat, dan lapangan Blue Carpet di Mapanget.

\section{RTH Pemakaman}

Pemakaman umum merupakan salah satu fasilitas sosial yang berfungsi sebagai tempat pemakaman bagi masyarakat yang meninggal dunia. Pemakaman umum juga memiliki fungsi lainnya seperti cadangan RTH, daerah resapan air, dan paru-paru kota. Lahan pemakaman selain digunakan untuk tempat pemakaman, umumnya memiliki sedikit lahan untuk ruang terbangun dan sisanya ditanami berbagai jenis tumbuhan. RTH Pemakaman di Kota Manado antara lain Taman Makam Pahlawan (Gambar 11a), serta pemakaman umum biasa (Gambar 11b) yang terdapat di setiap Kecamatan di Kota Manado. 


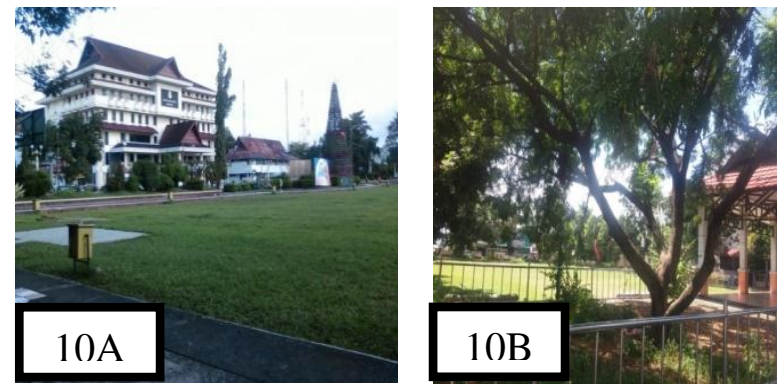

Gambar 10a. RTH Lapangan Olahraga Sparta Tikala 10b. RTH Lapangan Olahraga Lapangan Bantik Kecamatan .Malalayang.

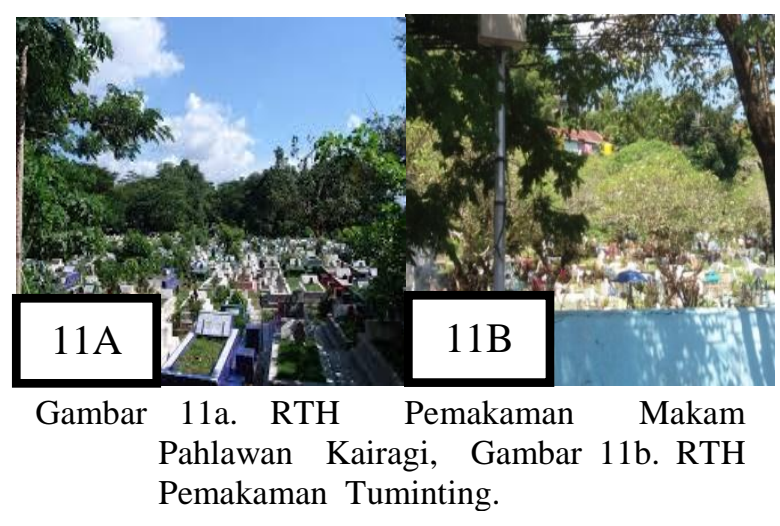

\section{RTH Perkarangan Rumah}

RTH perkarangan rumah merupakan lahan diluar bangunan yang luasnya disesuaikan. RTH pekarangan rumah termasuk dalam kelompok RTH privat. RTH perkarangan rumah di Kota Manado umumnya ditanami jenis tanaman bunga-bungaan, buah-buahan dan pohon-pohon kecil hingga sedang. Pada Gambar 12 merupakan RTH perkarangan rumah Kecamatan Malalayang.

\section{RTH Halaman Perkantoran, Tempat Usaha, Tempat Ibadah dan Sekolah}

RTH Halaman perkantoran dan tempat ibadah merupakan taman yang lebih kecil dan diperuntukan untuk populasi dan kegiatan terbatas, biasanya digunakan untuk kegiatan upacara, olahraga, sirkulasi udara dan sebagai elemen estetika. RTH ini umumnya belum cukup tersedia di lingkungan perkantoran dan bangunan komersial, sedangkan di lingkungan sekolah lebih banyak berupa ruang terbuka non hijau. Beberapa Instansi dan Universitas di Kota Manado memiliki ruang terbuka hijau seperti : kompleks Kantor Gubernur Sulawesi Utara, kompleks Kantor Walikota Manado, kompleks Polda Sulut, kompleks Kantor TNI AD, kompleks Kantor TNI AL, Universitas Samratulangi, kompleks Kantor Kec Malalayang (Gambar 13) serta beberapa Hotel besar memiliki RTH, namun untuk tempat ibadah rata-rata tidak memiliki ruang terbuka hijau dapat dilihat pada lampiran 2 .

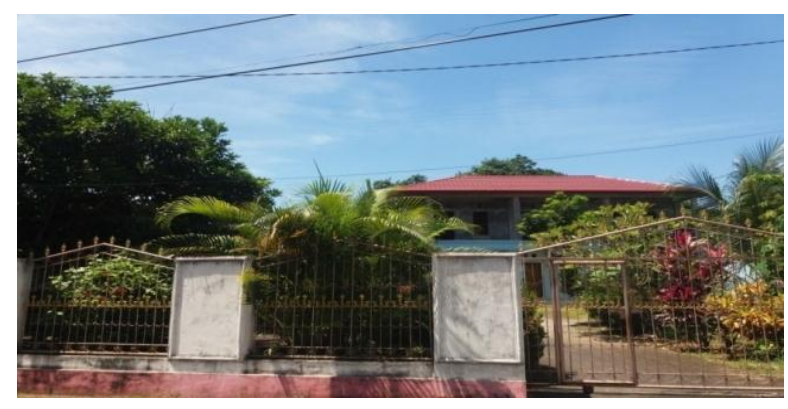

Gambar 12. RTH Perkarangan Rumah



Gambar 13. RTH Halaman Perkantoran Kantor Camat Kec.Malalayang.

\section{RTH Pertanian Kota/Kebun dan tambak Kegiatan pertanian tentunya} membutuhkan lahan yang cukup luas, sehingga kegiatan ini jarang ditemui di kawasan pusat kota yang cenderung kepada kegiatan perdagangan dan jasa. Di Kota Manado RTH pertanian kota, kebun, serta tambak terdapat pada hampir semua kecamatan di Kota Manado kecuali kecamatan Sario dan Kecamatan Mapanget merupakan kecamatan dengan RTH pertaniannya yang paling besar (Gambar 14). Kegiatan utamanya berupa budidaya pangan, hortikultura, kebun campuran, kolam ikan yang dikelola oleh masyarakat setempat. Pada Gambar 14 merupakan hasil gambar pertanian kota yang ada di Kecamatan Mapanget. Kecamatan Mapanget dan Kecamatan Bunaken merupakan dua kecamatan yang ada di Kota Manado dengan lahan RTH Pertanian kota terbesar. 


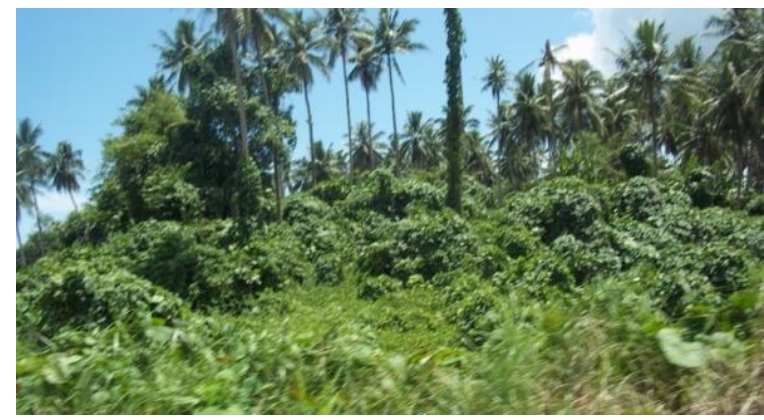

Gambar 14. RTH Perkarangan Rumah.

\section{Ketersedian Ruang Terbuka Hijau (RTH) Kota Manado}

Analisis ketersediaan RTH dilakukan untuk mengetahui jumlah eksisting ketersediaan RTH, jenis RTH, luas RTH, serta sebaran RTH yang ada di lokasi penelitian yaitu Kota Manado. Analisis yang digunakan yaitu mengidentifikasi ketersediaan RTH dari data sekunder yang diperoleh.

\section{RTH Kecamatan Malalayang Kota Manado}

Kecamatan Malalayang berada di sebelah selatan Kota Manado dengan luas wilayah 1712 Ha yang memiliki RTH publik sebesar 41,2 \% dan RTH privat sebesar 14,80 $\%$, secara keseluruhan RTH Kecamatan Malalayang dibagi kedalam 9 wilayah administrasi kelurahan yakni : Kelurahan Bahu, Kelurahan Batu Kota, Kelurahan Kleak, Kelurahan Malalayang 1 Barat, Kelurahan Malalayang 1 Timur, Kelurahan Malalayang 1, Kelurahan Malalayang 2, Kelurahan Winangun 1, dan Kelurahan Winangun 2. Pada Tabel 3 merupakan identifikasi ketersediaan RTH Kecamatan Malalayang Kota Manado. Pada Tabel 3 merupakan ketersediaan RTH yang ada di Kecamatan Malalayang Kota Manado dengan jenis RTH pertanian/perkebunan kota serta tambak dan jenis RTH alami memiliki luas lahan terbesar yang ada di Kecamatan Malalayang. Luas keseluruhan RTH di Kecamatan Malalayang sebesar 957,985 Ha dari luas wilayah $1712 \mathrm{Ha}$.

\section{RTH Kecamatan Sario Kota Manado}

Kecamatan Sario dengan luas wilayah 175 Ha memiliki RTH publik sebesar 26,4 \% dan RTH privat sebesar 78,5\%. Kecamatan ini berada diantara Kecamatan Malalayang dan Kecamatan Wanea, terdiri dari 7 wilayah administrasi kelurahan yakni Kelurahan Ranotana, Kelurahan Sario Kotabaru, Kelurahan Sario Tumpaan, Kelurahan Sario Utara, Kelurahan Sario, Kelurahan Titiwungen Selatan, dan Kelurahan Titiwungen Utara. Pada Tabel 3 merupakan ketersediaan RTH yang ada di Kecamatan Malalayang Kota Manado dengan jenis RTH pertanian/ perkebunan kota serta tambak dan jenis RTH alami memiliki luas lahan terbesar yang ada di Kecamatan Malalayang. Luas keseluruhan RTH di Kecamatan Malalayang sebesar 957,985 Ha dari luas wilayah $1712 \mathrm{Ha}$.

\section{RTH Kecamatan Sario Kota Manado}

Kecamatan Sario dengan luas wilayah 175 Ha memiliki RTH publik sebesar 26,4 \% dan RTH privat sebesar 78,5 \%. Kecamatan ini berada diantara Kecamatan Malalayang dan Kecamatan Wanea, terdiri dari 7 wilayah administrasi kelurahan yakni Kelurahan Ranotana, Kelurahan Sario Kotabaru, Kelurahan Sario Tumpaan, Kelurahan Sario Utara, Kelurahan Sario, Kelurahan Titiwungen Selatan, dan Kelurahan Titiwungen Utara. Pada Tabel 4 dapat dilihat merupakan identifikasi ketersediaan RTH yang ada di Kecamatan Sario Kota Manado dengan jenis RTH privat yaitu RTH perkarangan rumah dan RTH privat halaman tempat usaha memiliki luas lahan terbesar yang ada di Kecamatan Sario. Pada Kecamatan ini tidak terdapat RTH sempadan pantai, RTH hutan kota, RTH pemakaman dan RTH pertanian kota. Yang dimaksud RTH pemakaman yaitu lahan pemakaman yang memiliki lahan RTH kawasan penghijauan. Luas keseluruhan RTH di Kecamatan Sario sebesar 143,58 Ha dari luas wilayah Kecamatan Sario Kota Manado $175 \mathrm{Ha}$.

\section{RTH Kecamatan Wanea Kota Manado}

Kecamatan Wanea yang memiliki luas wilayah $785 \mathrm{Ha}$ terbagi atas 7 wilayah administrasi Kelurahan yaitu Karombasan Utara, Pakowa, Ranotana Weru, Tanjung Batu, Wanea, Teling Atas, dan Tingkulu. Kecamatan Wanea memiliki RTH publik sebesar 22,3\% dan RTH privat sebesar 16,4 \%. Pada Tabel 5 merupakan ketersediaan RTH yang ada di Kecamatan Wanea Kota Manado. 


\section{RTH Kecamatan Wenang Kota Manado}

Kecamatan Wenang terbagi ke dalam 11 wilayah administrasi Kelurahan yakni: Kelurahan Bumi Beringin, Calaca, Istiqlal, Lawangirung, Mahakeret Barat, Mahakeret Timur, Pinaesaan, Teling Bawah, Tikala Kumaraka, Wenang Selatan, dan Wenang Utara. Luas wilayah Kecamatan Wenang yaitu 364 Ha dengan RTH publik sebesar 9,04 $\%$ dan RTH privat sebesar $12,8 \%$ dari luas wilayah. Pada Tabel 6 dapat dilihat merupakan identifikasi ketersediaan RTH yang ada di Kecamatan Wenang Kota Manado dengan jenis RTH privat yaitu RTH perkarangan rumah memiliki luas lahan terbesar yang ada di Kecamatan Sario. Luas keseluruhan RTH di Kecamatan Wenang sebesar 79,83 Ha dari luas wilayah Kecamatan Wenang Kota Manado 364 Ha.

\section{RTH Kecamatan Tikala Kota Manado}

Kecamatan Tikala terbagi ke dalam 5 wilayah administrasi Kelurahan yakni : Kelurahan Tikala Baru, Kelurahan Tikala Ares, Kelurahan Taas, Kelurahan Banjer, kelurahan Paal 4. RTH publik Kecamatan Tikala sebesar 41,8 \% dan RTH privat sebesar 14,1\%. Pada Tabel 7 merupakan identifikasi ketersediaan RTH dengan luas keseluruhan RTH di Kecamatan Tikala sebesar 397,44 Ha dari luas wilayahnya sebesar $710 \mathrm{Ha}$.

\section{RTH Kecamatan Paal Dua Kota Manado}

Kecamatan Paal dua Terbagi atas 7 wilayah administrasi Kelurahan yaitu Kelurahan Dendengan Dalam, Kelurahan Dendengan Luar, Kelurahan Kairagi Weru, Kelurahan Malendeng, Kelurahan Paal 2, Kelurahan Perkamil, dan Kelurahan Ranomuut. RTH publik Kecamatan Paal Dua sebesar 6,9 \% dan RTH privat sebesar $67 \%$. Pada Tabel 8 merupakan identifikasi ketersediaan RTH dengan luas keseluruhan RTH di Kecamatan Paal Dua sebesar 600,89 Ha dari luas wilayahnya sebesar $802 \mathrm{Ha}$.

\section{RTH Kecamatan Mapanget Kota Manado}

Kecamatan Mapanget terbagi atas 8 wilayah administrasi Kelurahan yakni :
Kelurahan Bengkol, Kelurahan Buha, Kelurahan Kairagi 1, Kelurahan Kairagi 2, Kelurahan Kima Atas, Kelurahan Mapanget Bawah, Kelurahan Paniki 1, Kelurahan Paniki 2, dan Lapangan. RTH publik Kecamatan Mapanget sebesar 2,74 \% dan RTH privat sebesar 88,3 \%. Pada Tabel 9 merupakan identifikasi ketersediaan RTH dengan luas keseluruhan RTH di Kecamatan Mapanget sebesar 4687,41 Ha dari luas wilayahnya sebesar 4975 Ha.

\section{RTH Kecamatan Singkil Kota Manado}

Kecamatan Singkil terbagi ke dalam 9 wilayah administrasi Kelurahan yaitu : Kelurahan Karame, Kelurahan ketang Baru, Kelurahan Kombos Barat, Kelurahan Kombos Timur, Kelurahan Mapanget, Kelurahan Singkil 1, Kelurahan Singkil 2, Kelurahan Ternat Baru, dan Kelurahan Ternate RTH publik Kecamatan Singkil sebesar 9,1\% dan RTH privat sebesar 10,5\%. Pada Tabel 10 merupakan identifikasi ketersediaan RTH dengan luas keseluruhan RTH di Kecamatan Singkil sebesar 91,03 Ha dari luas wilayahnya sebesar $468 \mathrm{Ha}$.

\section{RTH Kecamatan Tuminting Kota Manado}

Kecamatan Tuminting terbagi ke dalam 9 wilayah administrasi yakni : Kelurahan Maasing, Kelurahan Sindulang 1, Kelurahan Sindulang 2, Kelurahan Mahawu, Kelurahan Sumompo, Kelurahan Tuminting, Kelurahan Tumumpa 1, Kelurahan Tumumpa 2, Kelurahan Bitung Karang Ria. RTH publik Kecamatan Tuminting sebesar 25,4\% dan RTH privat sebesar 17,86 \%. Pada Tabel 11 merupakan identifikasi ketersediaan RTH dengan luas keseluruhan RTH di Kecamatan Tuminting sebesar 186,39 Ha dari luas wilayahnya sebesar $431 \mathrm{Ha}$.

\section{RTH Kecamatan Bunaken Kota Manado}

Kecamatan Bunaken terdiri dari 5 wilayah administrasi yakni Kelurahan Bailang, Kelurahan Meras, Kelurahan Molas, Kelurahan Pandu, dan Kelurahan Tongkaina. RTH publik Kecamatan Bunaken sebesar 9,9 $\%$ dan RTH privat sebesar 75,7 \%. Pada 
Tabel 12 merupakan identifikasi ketersediaan RTH dengan luas keseluruhan RTH di Kecamatan Bunaken sebesar 3099,66 Ha dari luas wilayahnya sebesar $3619 \mathrm{Ha}$.

\section{RTH Kecamatan Kepulauan Bunaken Kota Manado}

Kecamatan Kepulauan Bunaken terdiri dari 3 pulau yaitu pulau Bunaken, pulau Manado Tua, dan pulau Siladen. RTH publik Kecamatan Kep. Bunaken sebesar $19,40 \%$ dan RTH privat sebesar 73,4 \%. Pada Tabel 13 merupakan identifikasi ketersediaan RTH dengan luas keseluruhan RTH di Kecamatan Kep. Bunaken sebesar 1564,76 Ha dari luas wilayahnya sebesar 1685 Ha. Hasil analisis pada Tabel 14 menunjukkan bahwa ketersediaan RTH Publik eksisting di Kota Manado terdiri dari RTH taman kota, RTH hutan kota, RTH jalur hijau jalan, RTH jalur hijau sempadan sungai, RTH jalur hijau sempadan pantai, RTH lapangan olahraga, RTH pemakaman, dan RTH alami. Dan Kecamatan Malalayang memiliki RTH Publik terbesar yaitu seluas 704.61 hektar dan kecamatan Wenang merupakan kecamatan di kota Manado yang memiliki RTH publik terkecil yaitu hanya seluas 32.91 hektar, dengan jumlah seluruh RTH publik yang ada di Kota Manado sebesar 2283,25 Ha atau hanya berkisar 14,51\% RTH publik dari luas wilayah kota Manado. Pada Tabel 15, Untuk ketersediaan RTH privat di Kota Manado terdiri dari RTH perkarangan rumah, RTH halaman perkantoran, RTH tempat usaha, RTH tempat ibadah, RTH sekolah, RTH tanah kosong dan RTH pertanian/perkebunan/tambak, kecamatan Mapanget yang memiliki RTH privat terbesar yaitu 4395.34 hektar dan untuk RTH privat terkecil juga pada kecamatan Wenang sebesar 46,92 hektar. Berdasarkan data yang diperoleh untuk RTH tempat ibadah pada Kecamatan Tikala, Paal Dua, Mapanget, Singkil, dan Tuminting kosong atau tidak ada, yang artinya tempat ibadahnya ada tetapi tidak memiliki lahan RTH. Jumlah seluruh RTH privat yang ada di Kota Manado sebesar 10223,57 Ha atau berkisar 65,01 \% RTH privat dari luas wilayah kota Manado.

\section{Kebutuhan Ruang Terbuka Hijau (RTH) Kota Manado}

Undang-Undang Nomor 26 Tahun 2007 pasal 29 tentang Penataan Ruang menetapkan bahwa proporsi RTH pada wilayah perkotaan minimal $30 \%$ dari luas wilayah, yaitu $20 \%$ RTH public dan $10 \%$ RTH privat. Analisis kebutuhan RTH berdasarkan luas wilayah di Kota Manado merupakan proses penentuan luas ruang terbuka hijau yang dibutuhkan berdasarkan luas wilayah perkotaan, dimana dalam Rencana Tata Ruang Wilayah (RTRW) Kota Manado direncanakan 30\% dari luas wilayah kota baik diisi oleh tanaman yang tumbuh secara alamiah maupun sengaja di tanam, dengan pembagian $20 \%$ RTH publik dan $10 \%$ RTH privat. Pada Tabel 16 dapat dilihat bahwa Kecamatan Mapanget dan Kecamatan Bunaken merupakan Kecamatan yang ada di Kota Manado yang membutuhkan luas RTH terbanyak atau terbesar.

\section{Kecukupan Ruang Terbuka Hijau (RTH) Kota Manado}

Kecukupan RTH di suatu wilayah diketahui dengan membandingkan kondisi ketersediaan (eksisting) dan kebutuhannya. Untuk analisis kecukupan RTH berdasarkan luas wilayah dapat dilihat pada Tabel 17. Pada Tabel 17 menunjukan bahwa ketersediaan RTH publik belum mencapai target $20 \%$ dari luas wilayah sedangkan RTH publik yang ada hanya berkisar 14,51\%, nilai ini belum mencukupi angka kebutuhan RTH publik diwilayah perkotaan yang berfungsi meningkatkan kualitas lingkungan perkotaan, sedangkan untuk RTH privat telah melebihi 5-6 kali lipat dari target yaitu $10 \%$ RTH privat dari luas wilayah dengan RTH privat yang dimiliki sebesar $62,47 \%$. Maka ketersediaan RTH privat masih lebih luas dari RTH Publik yang ada di Kota Manado. 
Tabel 1. Luas Wilayah Kota Manado Berdasarkan Per Kecamatan

\begin{tabular}{lcc}
\hline Kecamatan & Luas (Ha) & \% \\
\hline Malalayang & 1712 & 10,9 \\
Sario & 175 & 1,1 \\
Wanea & 785 & 5,0 \\
Wenang & 364 & 2,3 \\
Tikala & 710 & 4,5 \\
Paal Dua & 802 & 5,1 \\
Mapanget & 4975 & 31,6 \\
Singkil & 468 & 3,0 \\
Tuminting & 431 & 2,7 \\
Bunaken & 3619 & 23,0 \\
Kepulauan Bunaken & 1685 & 10,7 \\
\hline MANADO & 15726 & 100
\end{tabular}

Tabel 2. Jumlah Penduduk Kota Manado Berdasarkan Per Kecamatan

\begin{tabular}{llccc}
\hline & & & Jumlah Penduduk & Jumlah \\
\cline { 3 - 5 } No & Kecamatan & Laki-laki & 31.473 & 63.370 \\
\cline { 2 - 4 } 1. & Malalayang & 31.897 & 21.184 & 42.565 \\
2. & Sario & 21.381 & 31.956 & 63.044 \\
3. & Wanea & 31.088 & 26.538 & 52.202 \\
4. & Wenang & 25.664 & 24.363 & 49.135 \\
5. & Tikala & 24.772 & 26.015 & 52.629 \\
6. & Paal 2 & 26.614 & 25.795 & 52.174 \\
7. & Mapanget & 26.379 & 23.409 & 47.308 \\
8. & Singkil & 23.899 & 25.700 & 52.053 \\
9. & Tuminting & 26.353 & 20.849 & 41.943 \\
10. & Bunaken & 21.094 & 3.858 & 7.783 \\
\hline 11. & kep. Bunaken & 3.925 & $\mathbf{2 6 1 . 1 4 0}$ & $\mathbf{5 2 4 . 2 0 6}$ \\
\hline
\end{tabular}

Sumber : Data Hasil Olahan Analisis 2017

Tabel 3. Identifikasi Ketersediaan RTH Kecamatan Malalayang

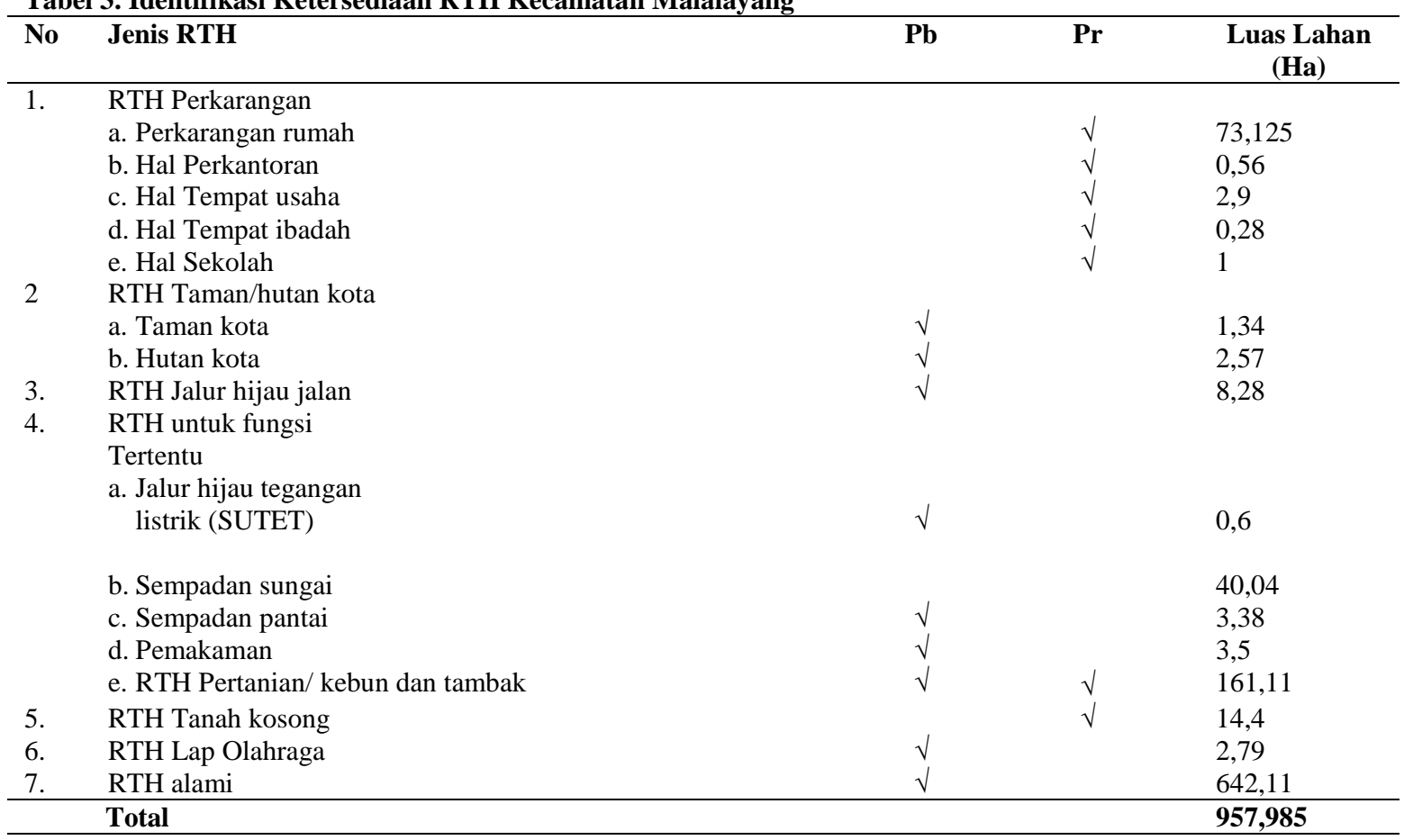

Sumber : BAPPEDA Kota Manado, Masterplan RTRW Kota Manado 2016 
Tabel 4. Identifikasi Ketersediaan RTH Kecamatan Sario

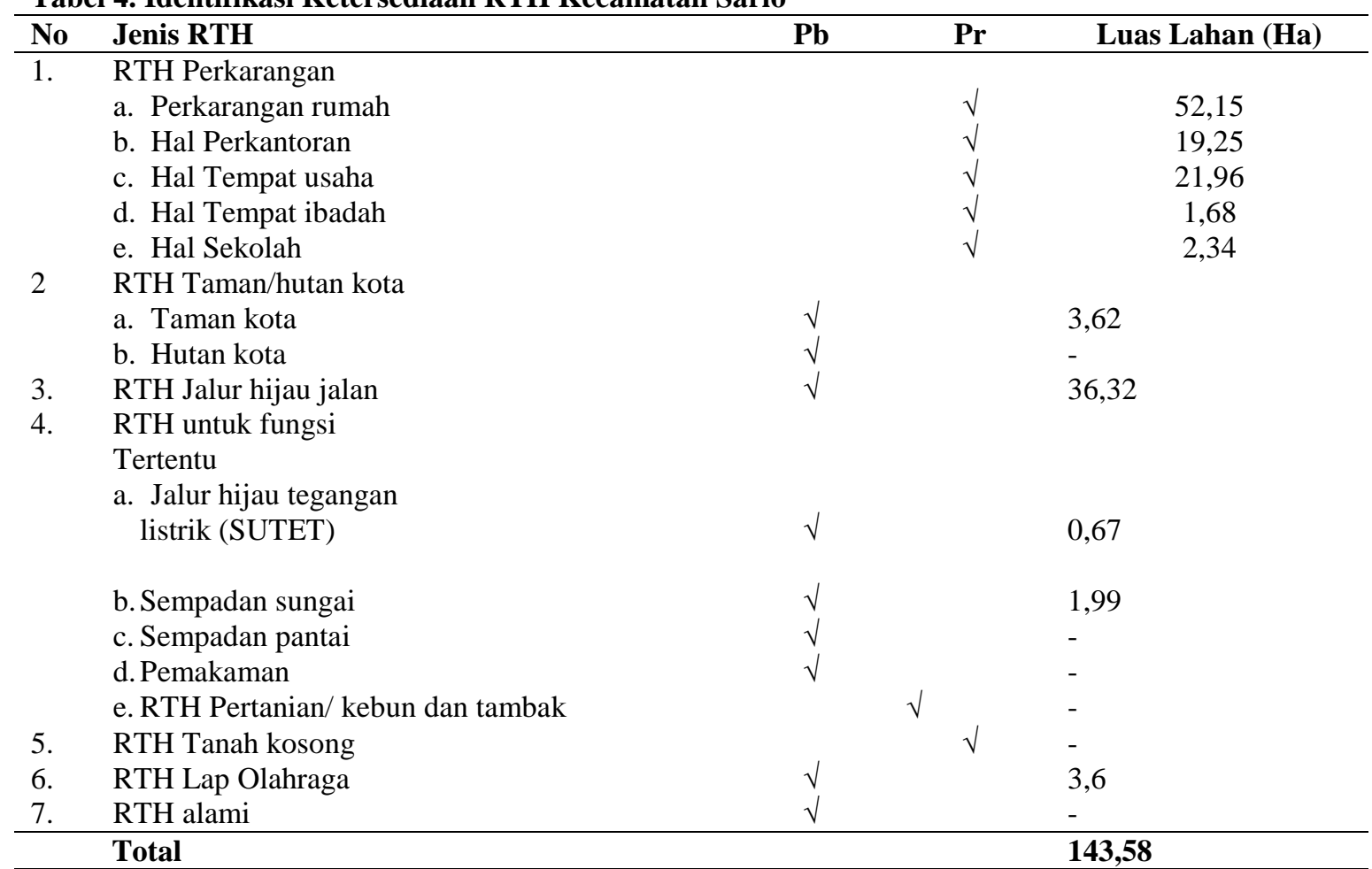

Sumber : BAPPEDA Kota Manado, Masterplan RTRW Kota Manado 2016

Tabel 5. Identifikasi Ketersediaan RTH Kecamatan Wanea

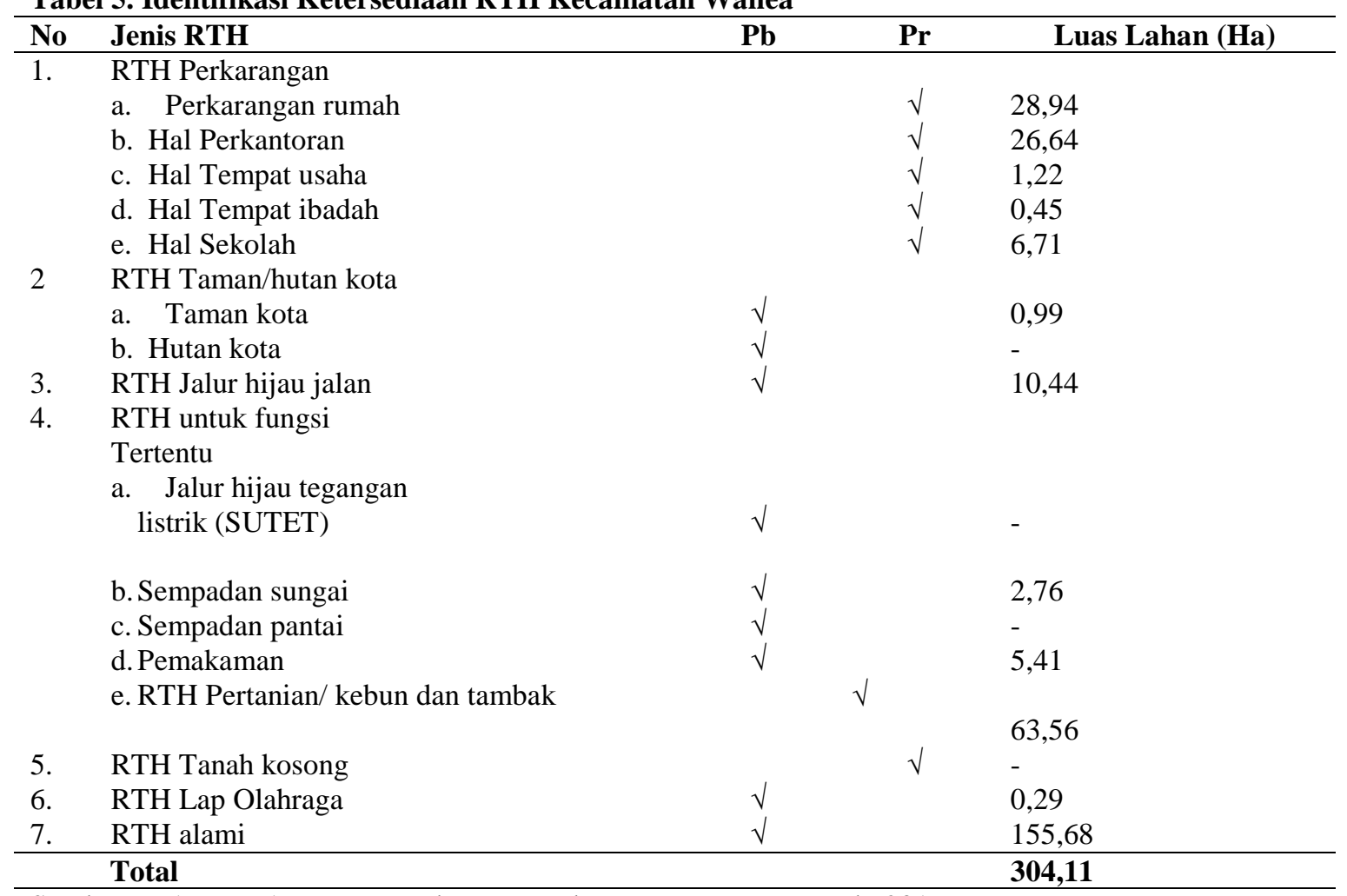

Sumber : BAPPEDA Kota Manado, Masterplan RTRW Kota Manado 2016 
Tabel 6. Identifikasi Ketersediaan RTH Kecamatan Wenang

\begin{tabular}{|c|c|c|c|c|}
\hline No & Jenis RTH & $\mathbf{P b}$ & Pr & Luas Lahan (Ha) \\
\hline \multirow[t]{6}{*}{1.} & RTH Perkarangan & & & \\
\hline & a. Perkarangan rumah & & $\sqrt{ }$ & 19,4 \\
\hline & b. Hal Perkantoran & & $\sqrt{ }$ & 3,47 \\
\hline & c. Hal Tempat usaha & & $\sqrt{ }$ & 7,44 \\
\hline & d. Hal Tempat ibadah & & $\sqrt{ }$ & 1,39 \\
\hline & e. Hal Sekolah & & $\sqrt{ }$ & 5,03 \\
\hline \multirow[t]{3}{*}{2} & RTH Taman/hutan kota & & & \\
\hline & a. Taman kota & $\sqrt{ }$ & & 0,41 \\
\hline & b. Hutan kota & $\sqrt{ }$ & & - \\
\hline 3. & RTH Jalur hijau jalan & $\sqrt{ }$ & & 11,27 \\
\hline \multirow[t]{8}{*}{4.} & RTH untuk fungsi & & & \\
\hline & Tertentu & & & \\
\hline & a. Jalur hijau tegangan & & & \\
\hline & listrik (SUTET) & $\sqrt{ }$ & & - \\
\hline & b. Sempadan sungai & $\sqrt{ }$ & & 0,56 \\
\hline & c. Sempadan pantai & $\sqrt{ }$ & & - \\
\hline & d. Pemakaman & $\sqrt{ }$ & & 2,13 \\
\hline & e. RTH Pertanian/ kebun dan tambak & \multicolumn{2}{|c|}{$\sqrt{ }$} & 6,73 \\
\hline 5. & RTH Tanah kosong & & $\sqrt{ }$ & 3,46 \\
\hline 6. & RTH Lap Olahraga & $\sqrt{ }$ & & - \\
\hline \multirow[t]{2}{*}{7.} & RTH alami & $\sqrt{ }$ & & 18,54 \\
\hline & otal & & & 79,83 \\
\hline
\end{tabular}

Sumber : BAPPEDA Kota Manado, Masterplan RTRW Kota Manado 2016

Tabel 7. Identifikasi Ketersediaan RTH Kecamatan Tikala

\begin{tabular}{|c|c|c|c|c|}
\hline No & Jenis RTH & $\mathbf{P b}$ & Pr & Luas Lahan (Ha) \\
\hline \multirow[t]{6}{*}{1.} & RTH Perkarangan & & & \\
\hline & a. Perkarangan rumah & & $\sqrt{ }$ & 16,36 \\
\hline & b. Hal Perkantoran & & $\sqrt{ }$ & 1,83 \\
\hline & c. Hal Tempat usaha & & $\sqrt{ }$ & 0,69 \\
\hline & d. Hal Tempat ibadah & & $\sqrt{ }$ & - \\
\hline & e. Hal Sekolah & & $\sqrt{ }$ & 0,98 \\
\hline \multirow[t]{3}{*}{2} & RTH Taman/hutan kota & & & \\
\hline & c. Taman kota & $\sqrt{ }$ & & 1,08 \\
\hline & d. Hutan kota & $\sqrt{ }$ & & - \\
\hline 3. & RTH Jalur hijau jalan & $\sqrt{ }$ & & 4,69 \\
\hline \multirow[t]{8}{*}{4.} & RTH untuk fungsi & & & \\
\hline & Tertentu & & & \\
\hline & a. Jalur hijau tegangan & & & \\
\hline & listrik (SUTET) & $\sqrt{ }$ & & - \\
\hline & a. Sempadan sungai & $\sqrt{ }$ & & 3,75 \\
\hline & b. Sempadan pantai & $\sqrt{ }$ & & - \\
\hline & $\begin{array}{l}\text { c. Pemakaman } \\
\text { c. Pal }\end{array}$ & $\sqrt{ }$ & & 1,32 \\
\hline & d. RTH Pertanian/ kebun dan tambak & \multicolumn{2}{|c|}{$\sqrt{ }$} & 80,16 \\
\hline 5. & RTH Tanah kosong & & $\sqrt{ }$ & 0,51 \\
\hline 6. & RTH Lap Olahraga & $\sqrt{ }$ & & - \\
\hline \multirow[t]{2}{*}{7.} & RTH alami & $\sqrt{ }$ & & 286,07 \\
\hline & Total & & & 397,44 \\
\hline
\end{tabular}

Sumber : BAPPEDA Kota Manado, Masterplan RTRW Kota Manado 2016 


\begin{tabular}{|c|c|c|c|c|}
\hline No & Jenis RTH & $\mathbf{P b}$ & Pr & Luas Lahan (Ha) \\
\hline \multirow[t]{6}{*}{2.} & RTH Perkarangan & & & \\
\hline & a. Perkarangan rumah & & $\sqrt{ }$ & 39,39 \\
\hline & b. Hal Perkantoran & & $\sqrt{ }$ & 1,84 \\
\hline & c. Hal Tempat usaha & & $\sqrt{ }$ & 10,42 \\
\hline & d. Hal Tempat ibadah & & $\sqrt{ }$ & - \\
\hline & e. Hal Sekolah & & $\sqrt{ }$ & 3,79 \\
\hline \multirow[t]{3}{*}{2} & RTH Taman/hutan kota & & & \\
\hline & e. Taman kota & $\sqrt{ }$ & & 3,94 \\
\hline & f. Hutan kota & $\sqrt{ }$ & & - \\
\hline 3. & RTH Jalur hijau jalan & $\sqrt{ }$ & & 3,21 \\
\hline \multirow[t]{8}{*}{4.} & RTH untuk fungsi & & & \\
\hline & Tertentu & & & \\
\hline & a. Jalur hijau tegangan & & & \\
\hline & listrik (SUTET) & $\sqrt{ }$ & & - \\
\hline & b. Sempadan sungai & $\sqrt{ }$ & & 12,85 \\
\hline & c. Sempadan pantai & $\sqrt{ }$ & & \\
\hline & d. Pemakaman & & & 10,02 \\
\hline & e. RTH Pertanian/kebun dan tambak & & $\sqrt{ }$ & 458,52 \\
\hline 5. & RTH Tanah kosong & & $\sqrt{ }$ & 31,14 \\
\hline 6. & RTH Lap Olahraga & $\sqrt{ }$ & & 1 \\
\hline \multirow[t]{2}{*}{7.} & RTH alami & $\sqrt{ }$ & & 24,77 \\
\hline & Total & & & 600,89 \\
\hline
\end{tabular}

Sumber : BAPPEDA Kota Manado, Masterplan RTRW Kota Manado 2016

Tabel 9. Identifikasi Ketersediaan RTH Kecamatan Mapanget

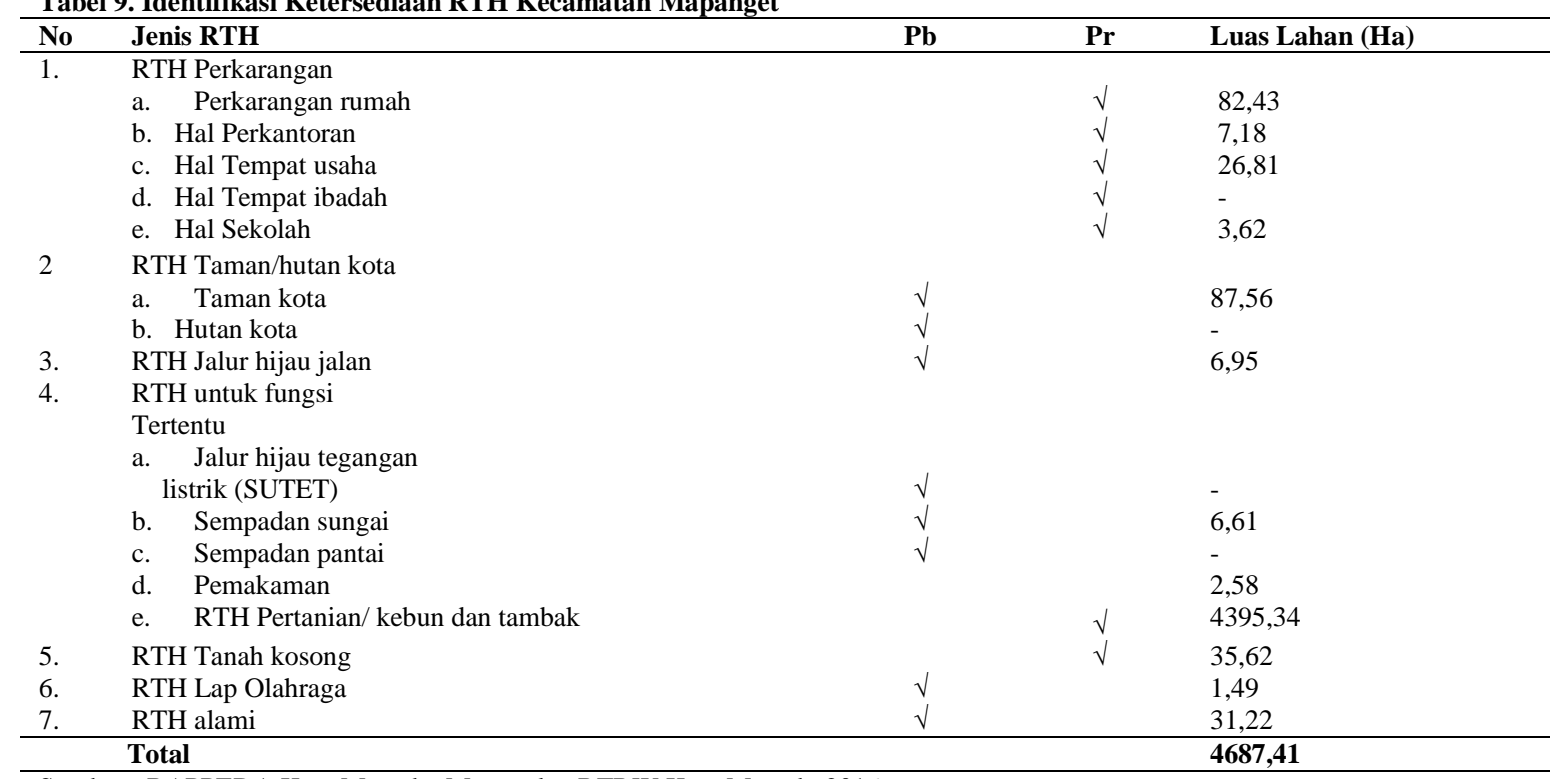

Sumber : BAPPEDA Kota Manado, Masterplan RTRW Kota Manado 2016 


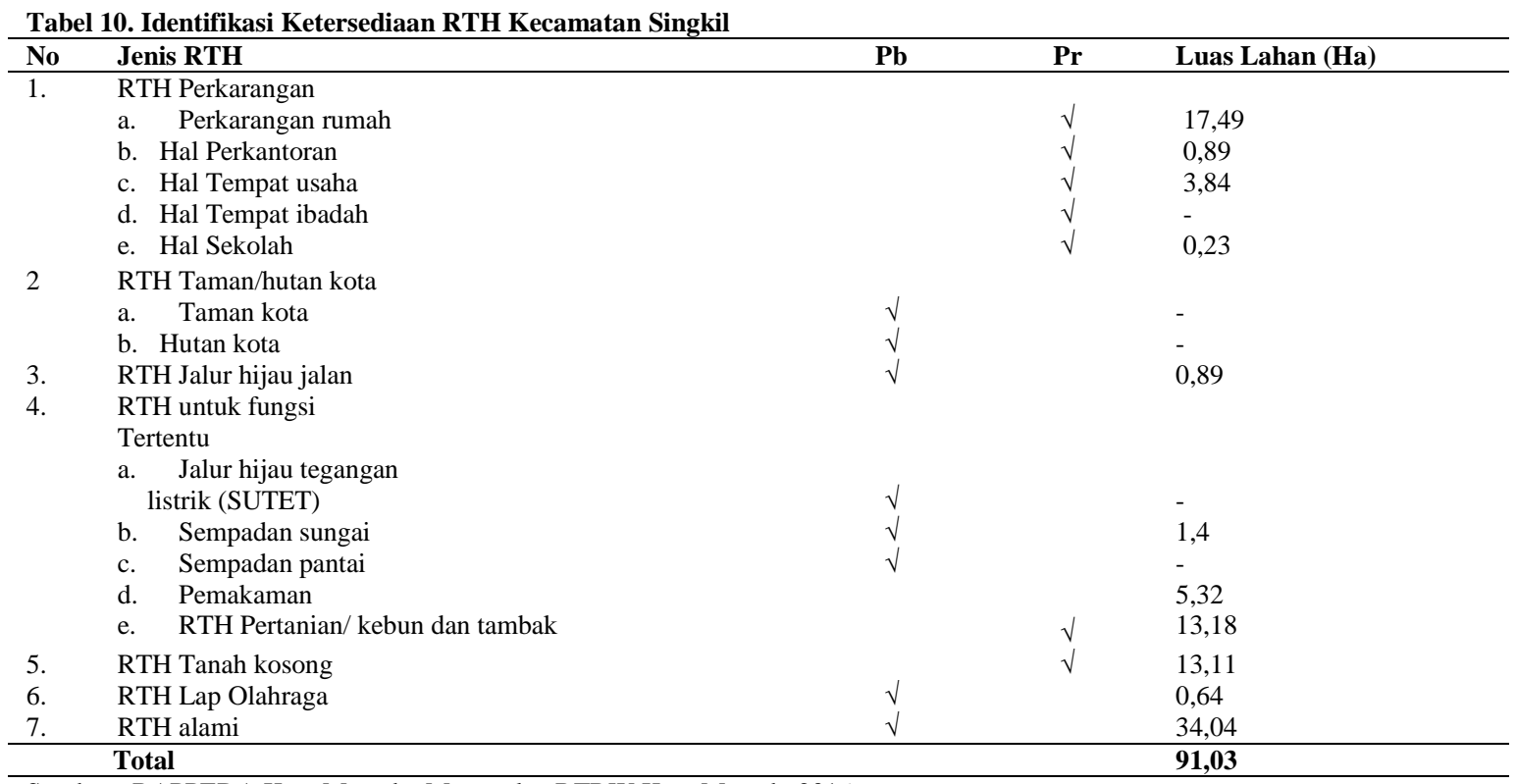

Sumber : BAPPEDA Kota Manado, Masterplan RTRW Kota Manado 2016

Tabel 11. Identifikasi Ketersediaan RTH Kecamatan Tuminting

\begin{tabular}{|c|c|c|c|c|}
\hline No & Jenis RTH & $\mathbf{P b}$ & Pr & Luas Lahan (Ha) \\
\hline \multirow[t]{6}{*}{1.} & RTH Perkarangan & & & \\
\hline & a. Perkarangan rumah & & $\sqrt{ }$ & 24,61 \\
\hline & b. Hal Perkantoran & & $\sqrt{ }$ & 2,03 \\
\hline & c. Hal Tempat usaha & & $\sqrt{ }$ & 4,39 \\
\hline & d. Hal Tempat ibadah & & $\sqrt{ }$ & - \\
\hline & e. Hal Sekolah & & $\sqrt{ }$ & 1,56 \\
\hline \multirow[t]{3}{*}{2} & RTH Taman/hutan kota & & & \\
\hline & a. Taman kota & $\sqrt{ }$ & & - \\
\hline & b. Hutan kota & $\sqrt{ }$ & & - \\
\hline 3. & RTH Jalur hijau jalan & $\sqrt{ }$ & & 3,89 \\
\hline \multirow[t]{8}{*}{4.} & RTH untuk fungsi & & & \\
\hline & Tertentu & & & \\
\hline & a. Jalur hijau tegangan & & & \\
\hline & listrik (SUTET) & $\sqrt{ }$ & & - \\
\hline & b. Sempadan sungai & $\sqrt{ }$ & & 0,62 \\
\hline & c. Sempadan pantai & $\sqrt{ }$ & & - \\
\hline & d. Pemakaman & & & 2,76 \\
\hline & e. RTH Pertanian/ kebun dan tambak & & $\sqrt{ }$ & 32,83 \\
\hline 5. & RTH Tanah kosong & & $\sqrt{ }$ & 11,2 \\
\hline 6. & RTH Lap Olahraga & $\sqrt{ }$ & & - \\
\hline \multirow[t]{2}{*}{7.} & RTH alami & $\sqrt{ }$ & & 102,5 \\
\hline & Total & & & 186,39 \\
\hline
\end{tabular}

Sumber : BAPPEDA Kota Manado, Masterplan RTRW Kota Manado 2016 


\begin{tabular}{|c|c|c|c|c|}
\hline No & Jenis RTH & $\mathbf{P b}$ & Pr & Luas Lahan (Ha) \\
\hline 1. & $\begin{array}{l}\text { RTH Perkarangan } \\
\text { a. Perkarangan rumah } \\
\text { b. Hal Perkantoran } \\
\text { c. Hal Tempat usaha } \\
\text { d. Hal Tempat ibadah } \\
\text { e. Hal Sekolah }\end{array}$ & & $\begin{array}{l}\sqrt{ } \\
V \\
V \\
V \\
V \\
V\end{array}$ & $\begin{array}{l}11,65 \\
- \\
6,72 \\
- \\
0,04\end{array}$ \\
\hline 2 & $\begin{array}{l}\text { RTH Taman/hutan kota } \\
\text { a. Taman kota } \\
\text { b. Hutan kota }\end{array}$ & $\begin{array}{l}\sqrt{ } \\
\sqrt{ }\end{array}$ & & $\overline{82,12}$ \\
\hline $\begin{array}{l}3 . \\
4 .\end{array}$ & $\begin{array}{l}\text { RTH Jalur hijau jalan } \\
\text { RTH untuk fungsi } \\
\text { Tertentu } \\
\text { a. Jalur hijau tegangan } \\
\text { listrik (SUTET) } \\
\text { b. Sempadan sungai } \\
\text { c. Sempadan pantai } \\
\text { d. Pemakaman } \\
\text { e. RTH Pertanian/ kebun dan tambak }\end{array}$ & $\begin{array}{l}\sqrt{ } \\
\sqrt{ } \\
\sqrt{ }\end{array}$ & $\sqrt{ }$ & $\begin{array}{l}- \\
1,77 \\
156,57 \\
- \\
2603,7\end{array}$ \\
\hline $\begin{array}{l}5 . \\
6 . \\
7 .\end{array}$ & $\begin{array}{l}\text { RTH Tanah kosong } \\
\text { RTH Lap Olahraga } \\
\text { RTH alami }\end{array}$ & $\begin{array}{l}\sqrt{ } \\
\sqrt{ }\end{array}$ & $\sqrt{ }$ & $\begin{array}{l}120,7 \\
- \\
112,71\end{array}$ \\
\hline & Total & & & 3099,66 \\
\hline
\end{tabular}

Sumber : BAPPEDA Kota Manado, Masterplan RTRW Kota Manado 2016

Tabel 13. Identifikasi Ketersediaan RTH Kecamatan Kepulauan Bunaken



Sumber : BAPPEDA Kota Manado, Masterplan RTRW Kota Manado 2016 
Agri-SosioEkonomi Unsrat, ISSN 1907-4298, Volume 13 Nomor 3, September 2017: 57 - 76

Tabel 14. Ketersediaan RTH Publik Kota Manado

\begin{tabular}{|c|c|c|c|c|c|c|c|c|c|c|c|}
\hline \multirow[b]{2}{*}{ Kecamatan } & \multicolumn{11}{|c|}{ Jenis RTH Privat } \\
\hline & $\begin{array}{c}\text { Taman } \\
\text { Kota }\end{array}$ & $\begin{array}{c}\text { Hutan } \\
\text { Kota }\end{array}$ & $\begin{array}{l}\text { Jalur } \\
\text { Hijau } \\
\text { Jalan }\end{array}$ & $\begin{array}{l}\text { Jalur } \\
\text { Sem. } \\
\text { Sungai }\end{array}$ & $\begin{array}{l}\text { Jalur } \\
\text { Sem. } \\
\text { Pantai }\end{array}$ & $\begin{array}{l}\text { RTH } \\
\text { Lab } \\
\text { Olaraga }\end{array}$ & $\begin{array}{c}\text { RTH } \\
\text { Pemakaman }\end{array}$ & $\begin{array}{c}\text { RTH } \\
\text { Alamiah }\end{array}$ & $\begin{array}{c}\text { Jumlah } \\
\text { (Ha) }\end{array}$ & $\begin{array}{c}\text { Luas } \\
\text { Wilayah }\end{array}$ & $\begin{array}{c}\text { Presentase } \\
\%\end{array}$ \\
\hline Malalayang & 1,34 & 2,57 & 8,28 & 40,04 & 3,38 & 2,79 & 3,5 & 642,11 & 704,01 & 1712 & \\
\hline Sario & 3,62 & - & 36,32 & 1,99 & - & 3,6 & - & - & 45,53 & 175 & $26,01 \%$ \\
\hline Wanea & 0,99 & - & 10,44 & 2,76 & - & 0,29 & 5,41 & 155,68 & 175,57 & 785 & $22,36 \%$ \\
\hline Wenang & 0,41 & - & 11,27 & 0,56 & - & - & 2,13 & 18,54 & 32,91 & 364 & $9,04 \%$ \\
\hline Tikala & 1,08 & - & 4,69 & 3,75 & - & - & 1,32 & 286,07 & 296,91 & 710 & $41,81 \%$ \\
\hline Paal Dua & 3,94 & - & 3,21 & 12,85 & - & 1 & 10,2 & 24,77 & 55,97 & 802 & $6,97 \%$ \\
\hline Mapanget & 87,56 & - & 6,95 & 6,61 & - & 1,491 & 2,58 & 31,22 & 136,411 & 4975 & $2,74 \%$ \\
\hline Singkil & - & - & 0,89 & 1,4 & - & 0,64 & 5,32 & 34,04 & 42,29 & 468 & $9,03 \%$ \\
\hline Tuminting & - & - & 3,89 & 0,62 & - & - & 2,76 & 102,5 & 109,77 & 431 & $25,46 \%$ \\
\hline Bunaken & - & 82,12 & 3,68 & 1,77 & 156,5 & - & - & 112,7 & 356,85 & 3619 & $9,86 \%$ \\
\hline $\begin{array}{l}\text { Kep. } \\
\text { Bunaken }\end{array}$ & - & - & - & - & $\begin{array}{l}7 \\
98,43\end{array}$ & - & - & 228,6 & 327,03 & 1685 & $19,40 \%$ \\
\hline Total (Ha) & 98,94 & 84,69 & 89,62 & 72,35 & 258,38 & 9,811 & 33,22 & 1636,24 & 2283,25 & 15726 & \\
\hline $\begin{array}{l}\text { Presentase } \\
(\%)\end{array}$ & $0,62 \%$ & $0,53 \%$ & $0,56 \%$ & $0,46 \%$ & $1,64 \%$ & $0,06 \%$ & $0,21 \%$ & $10,40 \%$ & $14,51 \%$ & & \\
\hline
\end{tabular}

Sumber : BAPPEDA Kota Manado, Masterplan RTRW Kota Manado 2016

Tabel 15. Ketersediaan RTH Privat Kota Manado

\begin{tabular}{|c|c|c|c|c|c|c|c|c|c|c|}
\hline \multirow[b]{2}{*}{ Kecamatan } & \multicolumn{10}{|c|}{ Jenis RTH Privat } \\
\hline & $\begin{array}{c}\text { RTH } \\
\text { Per. } \\
\text { Rumah }\end{array}$ & $\begin{array}{l}\text { RTH Hal. } \\
\text { Kantor }\end{array}$ & $\begin{array}{c}\text { RTH } \\
\text { Tempat } \\
\text { Usaha }\end{array}$ & $\begin{array}{l}\text { RTH } \\
\text { Tempat } \\
\text { Ibadah }\end{array}$ & $\begin{array}{c}\text { RTH } \\
\text { Sekolah }\end{array}$ & $\begin{array}{c}\text { RTH } \\
\text { Prtanian/ } \\
\text { Kebun/ } \\
\text { Tambak }\end{array}$ & $\begin{array}{c}\text { RTH } \\
\text { Tanah } \\
\text { Kosong }\end{array}$ & $\begin{array}{c}\text { Jumlah } \\
\text { (Ha) }\end{array}$ & $\begin{array}{c}\text { Luas } \\
\text { Wilayah }\end{array}$ & $\begin{array}{c}\text { Presentase } \\
\%\end{array}$ \\
\hline Malalayang & 73,125 & 0,56 & 2,9 & 0,28 & 1 & 161,11 & 14,4 & 253,37 & 1712 & $14,79 \%$ \\
\hline Sario & 52,15 & 19,25 & 21,96 & 1,68 & 2,34 & - & - & 97,38 & 175 & $55,64 \%$ \\
\hline Wanea & 28,94 & 26,64 & 1,22 & 0,45 & 6,71 & 63,56 & 1,33 & 128.85 & 785 & $16,41 \%$ \\
\hline Wenang & 19,4 & 3,47 & 7,44 & 1,39 & 5,03 & 6,73 & 3,46 & 46,92 & 364 & $12,89 \%$ \\
\hline Tikala & 16,36 & 1,83 & 0,69 & - & 0,98 & 80,16 & 0,51 & 100,53 & 710 & $14,15 \%$ \\
\hline Paal Dua & 36,39 & 1,84 & 10,42 & - & 3,79 & 458,52 & 31,14 & 542,1 & 802 & $67,59 \%$ \\
\hline Mapanget & 82,43 & 7,18 & 26,81 & - & 3,62 & 4237,86 & 35,62 & 4393,52 & 4975 & $88,31 \%$ \\
\hline Singkil & 17,49 & 0,89 & 3,84 & - & 0,23 & 13,18 & 13,11 & 48,74 & 468 & $10,41 \%$ \\
\hline Tuminting & 24,61 & 2,03 & 4,39 & - & 1,56 & 32,83 & 11,2 & 76,62 & 431 & $17,77 \%$ \\
\hline Bunaken & 11,65 & - & 6,72 & 156,57 & 0,04 & 26603,7 & 120,7 & 2899,38 & 3619 & $80,11 \%$ \\
\hline Kep. Bunaken & 4,3 & - & 7,34 & 98,43 & - & 1226,09 & - & 1237,73 & 1685 & $97,10 \%$ \\
\hline Total (Ha) & 366,845 & 63,69 & 93,73 & 258,8 & 25,3 & 9183,74 & 231,47 & 9825,14 & 15726 & \\
\hline Presentase $(\%)$ & $2,33 \%$ & $0,40 \%$ & $0,59 \%$ & $1,64 \%$ & $0,16 \%$ & $58,39 \%$ & $1,47 \%$ & $62,47 \%$ & & \\
\hline
\end{tabular}

Sumber: BAPPEDA Kota Manado, Masterplan RTRW Kota Manado 2016

Tabel 16. Kebutuhan RTH di Wilayah Kota Manado Berdasarkan Luas Wilayah

\begin{tabular}{|c|c|c|c|c|}
\hline Kecamatan & Luas Wilayah (Ha) & $\begin{array}{c}\text { Kebutuhan RTH Publik } \\
\text { (Ha) }\end{array}$ & $\begin{array}{c}\text { Kebutuhan RTH Privat } \\
\text { (Ha) }\end{array}$ & $\begin{array}{c}\text { Total Kebutuhan RTH } \\
\text { (Ha) }\end{array}$ \\
\hline Malalayang & 1712,0 & 342,4 & 171,2 & 513,6 \\
\hline Sario & 175,0 & 35,0 & 17,5 & 52,5 \\
\hline Wanea & 785,0 & 157,0 & 78,5 & 235,5 \\
\hline Wenang & 364,0 & 72,8 & 36,4 & 109,2 \\
\hline Tikala & 710,0 & 142,0 & 71,0 & 213,0 \\
\hline Paal 2 & 802,0 & 160,4 & 80,2 & 240,6 \\
\hline Mapanget & 4975,0 & 995,0 & 497,5 & 1492,5 \\
\hline Singkil & 468,0 & 93,6 & 46,8 & 140,4 \\
\hline Tuminting & 431,0 & 86,2 & 43,1 & 129,3 \\
\hline Bunaken & 3619,0 & 723,8 & 361,9 & 1085,7 \\
\hline Kep. Bunaken & 1685,0 & 337,0 & 168,5 & 505,5 \\
\hline Total & 15726 & 3145,2 & 1572,6 & 4717,8 \\
\hline
\end{tabular}


Tabel 17. Analisis Kecukupan RTH Berdasarkan Luas Wilayah Di Kota Manado

\begin{tabular}{lccccc}
\multicolumn{7}{c}{$\begin{array}{c}\text { Eksisting RTH } \\
\text { (Ha) }\end{array}$} & \multicolumn{2}{c}{$\begin{array}{c}\text { Kebutuhan RTH } \\
\text { (Ha) }\end{array}$} \\
Kecamatan & Publik & Privat & Publik & Privat & Kecukupan RTH \\
(Ha)
\end{tabular}

Sumber: BAPPEDA Kota Manado, Masterplan RTRW Kota Manado 2016

\section{KESIMPULAN DAN SARAN}

\section{Kesimpulan}

Dari hasil penelitian yang telah dilakukan di Kota Manado tentang ketersediaan ruang terbuka hijau (RTH), maka diperoleh kesimpulan sebagai berikut :

1. RTH publik yang ada di Kota Manado sebesar $2283,25 \mathrm{Ha}$ atau $14,51 \%$ dari total luas wilayah, hal ini berarti belum memenuhi syarat minimum yaitu $20 \%$ untuk RTH publik.

2. RTH privat yang ada di Kota Manado sebesar $9825,14 \mathrm{Ha}$ atau berkisar $62,47 \%$ dari total luas wilayah, telah melebihi hingga 6 kali lipat dari target RTH privat yaitu $10 \%$ dari luas wilayah kota Manado. Sehingga ketersediaan RTH privat masih lebih luas dari RTH publik.

3. RTH terluas pada Kecamatan Malalayang dengan luas RTH sebesar 957,38 Ha dan RTH terkecil pada Kecamatan Wenang sebesar 79,83 Ha.

\section{Saran}

1. Pemerintah perlu mengatur tata ruang yang terkait dengan kebutuhan RTH dalam upaya peningkatan kualitas lingkungan di Kota Manado berdasarkan luas wilayah, dan jumlah penduduk terutama ditekankan pada RTH publik karena hingga saat ini RTH publik masih kurang dari target.

2. Pengembangan RTH perlu diarahkan pada kecamatan-kecamatan yang nilai RTHnya terendah yaitu kecamatan Wenang, Singkil, dan Paal 2.

3. Keterbatasan lahan dapat menyebabkan penyediaan RTH publik disetiap kecamatan sulit dipenuhi terutama pada kawasan yang sudah terbangun. Karena itu penelitian selanjutnya dapat menganalisis kebutuhan RTH dan sebarannya pada kawasan-kawasan yang memang masih potensial untuk pengembangan RTH.

\section{DAFTAR PUSTAKA}

Anonimous, 1992. Daya Dukung Lingkungan Dan Komunikasi Massa dalam Pembangunan Berkelanjutan, Alfabeta. Bandung

Babo Prestin, 2016. Kenyamanan Termal Ruang Terbuka Hijau di Kampus Universitas Sam Ratulangi Berdasarkan Persepsi Pengunjung, Program Studi Ilmu Kehutanan Universitas Sam Ratulangi Manado 
Badan Pusat Statistik Sulawesi Utara. 2015. Sulut dalam angka. 2015. Sulawesi Utara.

Budihardjo,Eko. 1998. Tata Ruang Perkotaan, Alumni. Bandung

Hardika Erwin. 2012. Analisis Kebutuhan RTH Berdasarkan Pendekatan Kebutuhan Oksigen Menggunakan Citra Satelit EO-1 ALI (Earth Observer-1 Advanced Land Imager) Di Kota Manado. Balai Pengelolaan Daerah Aliran Sungai Tondano

Hakim.R,2000. Thesis Analisis Kebijakan Pengelolaan Ruang Terbuka Hijau Kota DKI Jakarta, Institut Teknologi Bandung.

Koestoer, H.Raldi. 2001. Dimensi Keruangan Kota. UI-Press.

Laoh, O. E. Harryani. 2002. Keterkaitan Faktor Fisik Faktor Sosial Ekonomi Dan Tataguna Lahan Di Daerah Tangkapan Air Dengan Erosi Dan Sedimentasi (Kasus Danau Tondano, Sulawesi Utara)

Maarebia. C, 2017. Identifikasi Ruang terbuka Hijau Di Kawasan Perumahan Griya Paniki Indah Kecamatan Mapanget Kota Manado. Skripsi. Program Studi Agroekoteknologi Universitas Sam Ratulangi

Monoarfa V. Richard, 2016. Evaluasi Ketersediaan Ruang Terbuka Hijau Dalam Mewujudkan Kota Hijau (P2KH), Jurusan Arsitektur Universitas Sam Ratulangi Manado.

Monoarfa V. Richard, 2016. Evaluasi Ketersediaan Ruang Terbuka Hijau Dalam Mewujudkan Kota Hijau (P2KH), Jurusan Arsitektur Universitas Sam Ratulangi Manado.
Pratama, M. Arszandi ,2015. Menata Kota Melalui Rencana Detail Tata Ruang (RDTR), ANDI OFFSET, Yogyakarta.

Pemendagri No.1 tahun 2007 .Fungsi dan Manfaat Ruang Terbuka Hijau (RTH).Permen PU No.05/PRT/M/2008 Pedoman Penyediaan dan Pemanfaatan Ruang Terbuka Hijau di Kawasan Perkotaan. Purnomohadi.N, 2006. Ruang terbuka hijau sebagai unsur utama tata ruang kota. Kebayoran Baru, Jakarta :Direktorat Jenderal Penataan Ruang, Departemen Pekerjaan Umum.

Santoso Budi, 2012. Pola Pemanfaatan Ruang Terbuka Hijau Pada Kawasan Perkampungan Plemburan Tegal Ngaglik Sleman, Jurusan Pendidikan teknik Sipil dan Perencanaan FT UNY.

Sutarni Arifin.Analisis Kebutuhan Ruang Terbuka Hijau Kecamatan Kota Tengah. Skripsi. Jurusan Teknik Arsitektur Universitas Negeri Gorontalo.

Sumarauw Alvira,2016. Analisis Kebutuhan Ruang Terbuka Hijau Publik Di Kota Bitung. Skripsi. Jurusan Perencanaan Wilayah Universitas Sam Ratulangi Manado.

Selly Triastuti, 2011. Identifikasi Ruang Terbuka Hijau Di Kecamatan Sukasari Kota Bandung. Skripsi. Universitas Pendidikan Indonesia.

Sulistyantara, B. 2002. Sistem dan Bentuk Ruang Terbuka Hijau Kota. Prosiding Pelatihan Ruang Terbuka Hijau. Studio Arsitektur Lanskap, Jurusan Budidaya Pertanian, Institut Pertanian Bogor. 
Undang-undang Republik Indonesia Nomor 26 Tahun 2007 Tentang Penataan Ruang
Yermias E. Lay, 2009. Kajian Kondisi Ruang Terbuka Hijau (RTH) Di Kelurahan Lailai Bisi Kopan (LLBK) Kota Kupang, Politeknik Negeri Kupang 